\title{
Observation of Biochemical Property in Brain Tissue of Fish Channa punctatus and Exposed to Deltamethrin
}

\author{
Mishra D.B ${ }^{1 *}$, Dubey J.K ${ }^{2}$, Singh Prashant ${ }^{3}$ and Tripathi V.K ${ }^{4}$ \\ ${ }^{1,2,3,4}$ Department of Zoology, T.D.P.G. College, Jaunpur, India \\ *Corresponding author : devbrat1003@gmail.com, Mob No - +919452660999
}

Available online at: www.isroset.org

Received: 05/Oct/2018, Accepted: 20/Oct/2018, Online: 31/Oct/2018

\begin{abstract}
The concept of pesticides is known from ancient time and available in literature around 1000 BCE. Homer referred to the use of sulfur to fumigate homes and by 900 C.E. Synthetic pesticides emerged between $1930 \& 1940$ as the result of research aimed at developing chemical weapons that were originally tested in insects. The fishes are directly exposed with water containing pesticides \& other water soluble pollutants; in hepatocytes detoxification of pesticides takes place and being a neurotoxic nature of deltamethrin, braius, gills \& liver tissues were selected to assess the deltamethrin toxicity.
\end{abstract}

Keywords : Deltamethrin, D.O., LC 50

\section{INTRODUCTION}

Water provides a good medium for growth of aquatic flora and fauna with great biodiversity. Major problem associated with the natural and man made water bodies across the globe is its pollution. Pollutants are ranging from natural to synthetic, nontoxic to highly toxic, degradable to non biodegradable. i.e. Xenobiotic compounds. These pollutants also destroy the quality of the aquatic media and render it unifit various aquatic, particularly fishes. These aquatic ecosystem comprising greater part of the natural environment is also faced with the. threat of a shrinking genetic base \& biodiversity (Ramamurthy et.al., 2009). A variety of organophosphate, organochloride, organometallic \& carbamide pesticides are extensively used in agriculture for the control of pests. The toxicity level were influenced by the sex and the nutrients supply (Arunachalam 1980; Sharma \& Ansari 2010). Pesticides exert many physiological $\&$ biochemical changes by influencing the activities of various enzymes of organisms. Altered chemical environment of the natural aquatic bodies has profound effect on behavioural and physiological system of inhabitants, specially the fishes (Khan \& Law, 2005).

The oxidative stress is an inescaple component of aerobic life. In the aerobic organism, a balance between the reactive oxygen species (ROS) production \& the system to protect. Cells from reactive oxygen species exists (Davies, 1995). The most important enzymes for detoxification A ROS in all organisms are SOD, CAT, GPx, Xanthine oxidase \& G6 PD. (Mishra D.B. et.al. 2008-09, Dubey, J.K. et.al.,2016), N. Liyana et.al. 2017. Deltamethrin belongs to the synthetic pyrethroids that are most popular \& widely used insecticides all over the world.

\section{MATERIALS AND METHODS}

Glasswares used in present investigation were a "Borosil make" Glasswares rinsed with double distilled water and dried in a hot air oven at $100^{\circ} \mathrm{C}$ for over night. Most of the chemical used from Hi Media, Sisco, SRL India. All the general chemicals used were AR grade.

Water Analysis of Experimental Site - The examination of physio-chemical characteristics of water carried out by standard methods as APHA 2005.

Temperature - At the time and sampling on the site in degree centigrade.

pH - pH was ensured in laboratory with the help of systronic $\mathrm{pH}$ meter (Model 324).

D.O. - Winkler's method was used for the estimation of dissolved oxygen in water.

\section{Total Alkalinity -}

The alkalinity of water can be determined by titrating the water samples with sulphuric acid of known values of $\mathrm{pH}$, Volume and concentration. Based on stoichiometry of the reaction and number of moles of sulphuric acid needed to reach the end point, the concentration of alkalinity in water is calculated.

\section{Collection \& Acclimatization of Fish -}

The adult $\&$ healthy fishes, irrespective of sex $(17.80+0.50$ cm length \& $47.85+$ weight) of Channa punctatus were 
collected from Gujartal Jaunpur. The collected fishes were airbreathing teleost cat fish. The fish were transported in plastic containers to the laboratory \& washed with 0.1 $\mathrm{KMNO}_{4}$ solution. Prior to the starts of experiments the fish were acclimatized to the laboratory condition for 15 days in dichlorinated tap water.

They were maintain glass aquaria containing dichlorinated tap water. The commercial grade pesticide deltamethrin was dissolved in acetone and required volume of the desired concentration of pesticides in added in each aquarium. The aquarium was replaced every $24 \mathrm{hrs}$ with fresh water in control \& deltamethrin solution, were mixed into the water aquarium. Feeding of fish was stopped $48 \mathrm{hrs}$ prior to the commencement of the experiment with a view to avoid and possible change in situ in the toxicity of pesticide.

\section{Determination of $\mathrm{LC}_{\mathbf{5 0}}$}

Bioassay or toxicity tests were carried out for the determination of $\mathrm{LC}_{50}$ values by following $\mathrm{FAO}$ procedure for short term bio-assays (Reish \& Oshida, 1987).

\section{Biochemical Studies -}

The fishes were sacrificed by decapitation \& tissues, where taken out $\mathrm{s}$ thoroughly washed \& cleaned in chilled $\mathrm{KC}$ 10.15 $\mathrm{M}$ to remove the blood \& adhering tissues.

The specimen were sacrificed, the brain removed, cleaned \& weighed rapidly. A ten percent (w/v) homogenate of different tissues were prepared in cold fish saline with the aid of potter Elvehjem type homogenizer fitted with the teflon pestle. The homogenate was fish centrifuged at 2000 rpm for 15 minutes in a refrigerated centrifuge, the pellet consisting of a nuclear fraction \& cell debris is discarded. The supernatent again centrifuge at $8000 \mathrm{rpm}$ for 20 minutes for the post mitochondrial supernatent, and taken for the biochemical studies \& crude enzyme studies.

Estimate the total carbohydrate by added $4 \mathrm{ml}$ of the anthrone reagent to $1 \mathrm{ml}$ of a protein free carbohydrate solution and rapidly mixed. Protein estimation in post mitochondrial and cystosolic supernatent was carried out by the Lowry et.al. 1951. Briefly, the lipid samples \& standards are placed in a heating block set at $100^{\circ} \mathrm{C}$ to allow the solvent to evaporate. Once the solvent is gone (about 10 min.) $0.1 \mathrm{ml}$ of concentrated sulfuric acid is added to each tube; vortexed, the heated $100^{\circ} \mathrm{C}$ for $10 \mathrm{~min}$. Samples are then removed from the heat block and allowed to cool to room temperature before adding $2.4 \mathrm{ml}$ of Vanillin reagent $\&$ vortexed.

\section{RESULT AND DISCUSSION}

The physical and chemical conditions of a water bodies gives it to living and setting the hydrodynamics of the water bodies. Several parameters are taken into account \& considered to the prime and are temperature, change in acid $\&$ based strength, dissolved oxygen concentration with play critical role and directly affect the aquatic flora and fauna. and its diversity, physico-chemical parameters of water was recorded \& presented in following tables 1.

Physico-chemical Properties of Water Bodies -

\begin{tabular}{|l|l|l|}
\hline S.No. & & \\
\hline 1. & Temperature & $\mathbf{2 6 . 5}^{\mathbf{0}} \mathbf{C}$ \\
\hline 2 & $\mathrm{pH}$ & 7.3 \\
\hline 3 & D.O. & $5.8 \mathrm{ppm}$ \\
\hline 4 & $\begin{array}{l}\text { Total } \\
\text { Alkalinity }\end{array}$ & $\begin{array}{l}\text { methyl orange- 265 ppm } \\
\text { phenolphthalein - Nil }\end{array}$ \\
\hline
\end{tabular}

Bioassay or toxicity tests were carried out for the determination of $\mathrm{LC}_{50}$ values by following $\mathrm{FAO}$ procedure for short term bio assays (Reish \& Oshida, 1987). The duration of the tests was 96 hrs stock solution of deltamethrin $10 \%$ effective concentration (EC) was prepared by diluting $1 \mathrm{ml}$ insecticides in $100 \mathrm{ml}$ of distilled water, and was prepared by diluting concentration of $0.01,0.02,0.03$, $0.04,0.05,0.06,0.08 \mathrm{ppm}$ which were used as experimental waters for toxicity study of selected model animal channa. The experiment was set in duplicate \& healthy fishes $(n=10)$ were maintained in 10 litre of experimental water having different concentration of deltamethrin. Similarly a control was set up with water devoid of deltamethrin. Feeding was stopped one day prior to the experiment and also during the experimental period, as recommended by Ward \& Parrish (1982) and Reish \& Oshida (1987). The LC $_{50}$ values were calculated as average from the two replicates for each experimental concentration of water by arithmetic graph method as showing graph-1 (Reish \& Oshida, 1987). LC Fo $_{50}$ at $96 \mathrm{hrs}$ were four at $1.3 \mathrm{ppm}$.

\section{Carbohydrate Contents -}

Carbohydrate content in different tissue are different and are showing progressive decreasing profile. Carbohydrate content in brain tissues was evaluated in test animal in Channa punctatus was found 1.6, $1.08,0.8 \& 0.3 \mathrm{mg} / \mathrm{gm}$ of wet weight of tissues as compared with control $(2.5 \mathrm{mg} / \mathrm{gm}$ of tissue) at 24, 48, $72 \& 96 \mathrm{hrs}$ respectively as shown in graph-1. The decreased level of carbohydrate contents in organs of the fish after $96 \mathrm{hrs}$ exposure with deltamethrin in brain tissues when compared to control.

Decreasment in carbohydrates level indicates in rapid utilization to meet and the increased energy demand to cope up with stress due to deltamethrin toxicity. The demand is channelized either glycolytic pathway or oxidative reaction of pentose phosphate pathway (Cappon et.al. 1975, Prusty et.al. 2015 \& Amin et.al. 2012, Dubey J.K. et.al. 2016). The carbohydrate content reduction is more prevalent under hypxic condition due to stress produced by a pesticides or heavy metals. (Dezwann et.al. 1972, Chandrawathy \& 
Reddy, 1995, Winkle et.al. 2007, Singh A.K. et.al. 2009 \& Yunsus et.al. 2015).

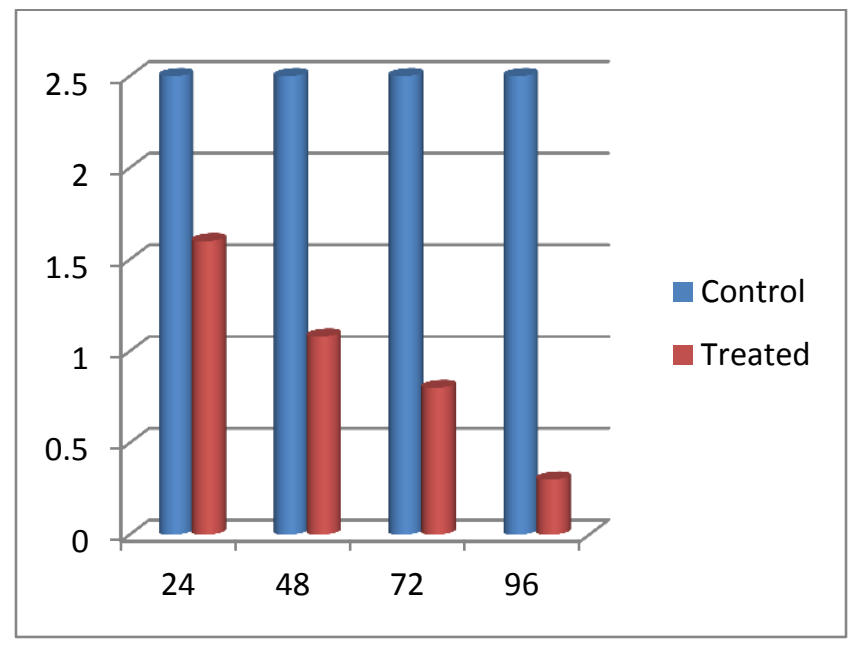

Time in hours

Graph -1 : Carbohydrate content in brain tissues

\section{Protein Content -}

Proteins are very important biomolecules and building block of organisms and considered as final class of biomolecules as for as energy requirement is concerned. Protein content in brain tissue were found to be $60.3,53.4,48.3 \& 39.2 \mathrm{mg} / \mathrm{gm}$ of we weight of tissues as compared with control 68.6 $\mathrm{mg} / \mathrm{gm}$ of tissue at $24,48,72 \& 96 \mathrm{hrs}$ respectively is shown in graph-2.

In present study the protein content was found to be decreased in all organs after the treatment with deltamethrin upto $96 \mathrm{hrs}$ when compared with the control. The decreased level of proteins might be due to inhibition of translational process are increased rate of metabolism of protein which may be entered Krebs cycle. Carried out due to deltamethrin stress (Ganeswade 2011, Binu Kumari \& Vasanthi 2013, Dubey J.K. et.al. 2016).

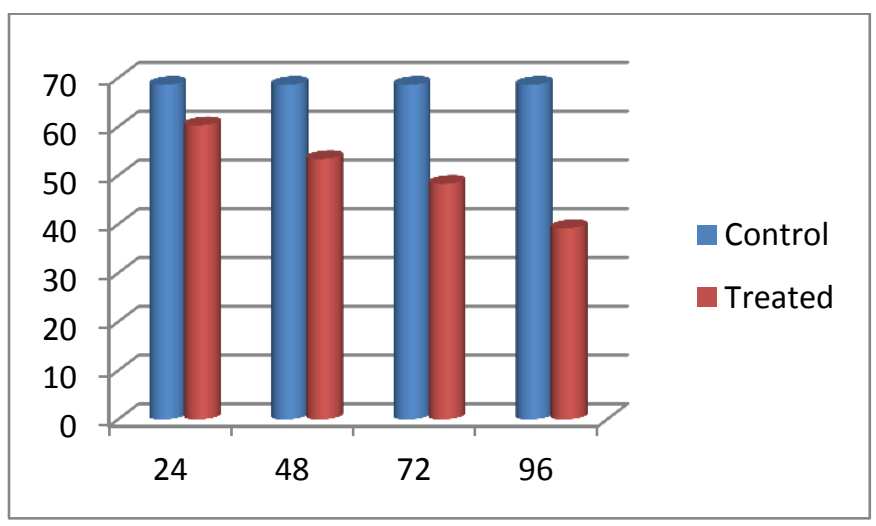

Time in hours

Graph-2: Protein content in brain tissues

\section{Lipid Contents -}

Lipids are important constituent of cell membrane and it also provide buoyancy to aquatic organism. Lipid content in brain tissue was found to be $18.2 \mathrm{mg} / \mathrm{gm}$ of wet weight of tissue in Channa punctatus was observed at $0,24,48,72$ \& $96 \mathrm{hrs}$ respectively. In treated brain tissue of Channa punctatus, the lipid content was found to be 16.3, 13.2, 11.3 $\& 8.8 \mathrm{mg} / \mathrm{gm}$ observed at set time intervals shown as graph3.

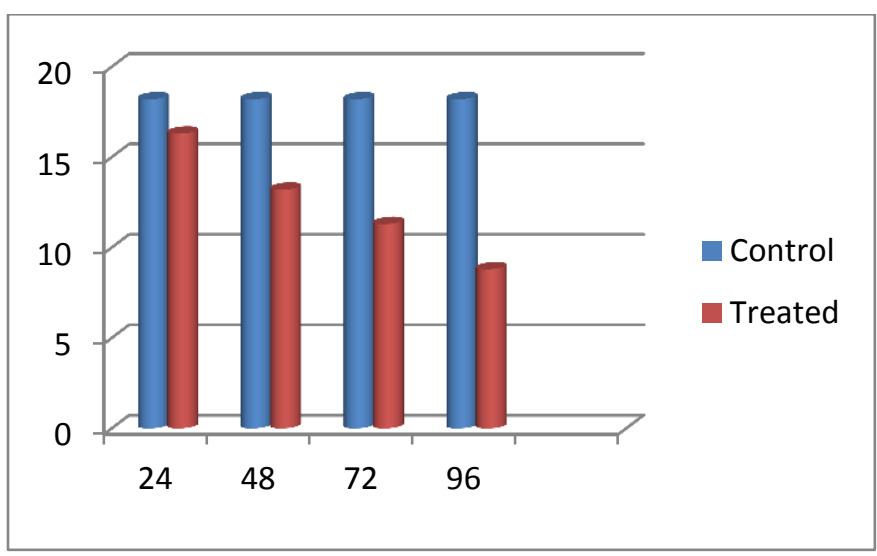

Time in hours

Graph-3: Lipid content in brain tissues

Lipid are important Biochemical constituent \& upon oxidation contributes a significant amount of energy via beta oxidation \& structural components for reproductive growth (Surgent 1995, Kylie et.al. 2013). It is due to exposure of deltamethrin that in term resulting into exhaust of energy during stress leading, to oxidation of lipids to meet out the organisms high energy demand.

\section{CONCLUSION}

The carbohydrate content in brain tissues was evaluated in Channa punctatus. The decreased level of carbohydrates contents in organs of fish after 96 hours exposure with deltamethrin in all tissues when compared to control. Decreasment in carbohydrates level indicates in rapid utilization to meet and the increased energy demand to cope up with the stress due to deltamethrin toxicity. this demand is channelized either glycolitic pathway of oxidative reaction of pentose phosphate pathway.(Cappon et.al.1975,Prusty et.al.2015).

The protein contents found to be destroyed in all organs after the treatment with deltamethrin upto 96 hours when compared with control . this decreased level of protein might be due to inhibition of translational process are increased high rate of catabolism of protein which may be entered into Krab's cycle via transmination process carried out by amino transferase and it might due to meet out organism high energy demand due to deltamethrin stress.

Reduced level of lipid contents in brain tissues after 96 hours exposure to deltamethrin . this reduction in absorption 
of carbohydrates and protein which in turn resulting into exhaust of energy during stress leading to oxidation of lipid to meet out the organic high energy demand.

\section{REFERENCES}

[1]. Lowry, O.H., Rosenbrough N.J., Farr A.L. \& Randall R.J. (1951). Protein measurement with the Folin Phenol reagent. J. Biol. Chem. 193 : 265-268.

[2]. Dezwaan A., \& Zandee D.I. (1972) : Body distribution and seasonal changes in glycogen content of the common sea mussel, comparative Biochem. Physiol. 43(A) : 53-56.

[3]. Cappon I.D., Nicholas D.M. (1975) : Factors involved in increased protein synthesis in live microsome after administration of DDT pesticides. Biochem. Physiol. 5:109-118.

[4]. Arunachalam, S.K., Jayalaxmi \& Abooboker S. (1980) : Toxic and sublethal effects of carbaryl on fresh water fish, Mystus vittatus, Arch.-Environ. Contam. Toxiol. 2: 307-316.

[5]. Ward, G.S., Parrish, P.R. (1982) : Toxicity Teots. In Mannual of methods in Aquatic Environment Research, Part-6, FAO Tech. Pap. $185: 1-12$.

[6]. Reish, D.L. \& Oshida, P.S. (1987). Manual of Methods in Aquatic Environment research, Part-10, Short-term bioassays, FAO-Tech. 247-262.

[7]. Chandrawath M., Reddy SLN (1995) : In vivo effects of lead acetate on dehydrogenas activities and metabolites in the fresh water fish, Anabus \& candes J. Ecotoxiol. Environ. Monit. 5(2) : 107-111.

[8]. Davies, KJA (1995) : Oxidative stress, the paradoxi of aerobic life. In : Rice-Evans C, Halliwell B, Land G.G. editors. Free radical and Oxidative Stress : Environment, Drugs and Food Additives, London : Portland Press, p. 1-31.

[9]. Surgent, J.R. : (1995) : Origin and functions of egg lipids nutritional implications in broodstock management and egg and larval quality, 353-372s.

[10]. APHA (2005) : Standard Methods for the examination of water and waste water, $21^{\text {st }}$ Washington DC USA : American Public Health Association.

[11]. Khan, MZ and Law, FCP (2005) : Adverse effects of Pesticides and related chemicals on Enzyme and Hormone Systems of Fish. Amphibians and Reptiles, Proc. Pakistan Acad. Sci. 42(4) : 315323.

[12]. Winkle,D.B.Nishn \& V.B. Singh 2007. Impact of pollution in Gomati river on Antioxidant response in gills of $\mathrm{H}$. fossilis. Asian J. Env. Sci. 2 (1\&2, 73-76).

[13]. Mishra Devbrat, Winkle \& Singh V.B. 2008-09. Distribution of anti-oxidonant enzyme SOD in Gomti \& Ganga River in Liver \& skin of Cirrhinas mrigala (Ham.) Asian J. Env. Sci. 3(2), 128130

[14]. A.K. Singh, J.K. Dubey, D.B. Mishra, G. Singh \& V.B. Singh 2009. Comparative study of Endosulphon effect on antioxidant enzyme of air breathing fresh water teleost, Clarias batrachus (Linn.) \& Heteropneustes fossilis. 2009. The Asian J. of Animal Sci. 4(1) 22.25.

[15]. Ramamurthy,v.,Venkatesh.A and Raveendran ,S.(2009).: effect of Spirulina platensis on the immunity and survival of Aeromonas salmonicida infected fish. I.Ecotoxicol. Environ.Monit, 19(6):July.576.

[16]. Sharma, D. \& B. Ansari (2010) : Effect of synthetic pyrethroit Deltamethrin and neem based pesticides : Arch. Polish. Fish 18 : 157161.

[17]. Ganeshwade R.M. (2011) : Biochemical changes induced by Dimethoate in the Liver of fresh water fish Puntius ticto (HAM). Biological Forum 3(2) 65-68.

[18]. Amin, K.A., Hashm K.S. (2012) : Deltamethrin-induced oxidative stress and biochemical changes in tissues and blood of catfish antixoidant denfene \& role alphatocopherol. BMC Vet. Res. $8: 45-52$.

[19]. Binu Kumari \& J. Vasanthi (2013) : Changes in protein content of the fresh water fish, Labeo rohita due to effect of an insecticide Encounter Int. J. Curr. Microbial. Asp. Sci. 2(10) 150-153.

[20]. Kylie R., Dunning : Darryl L. Russell; \& Rebecca L. Robker (2013) : Lipids and ocytes developmental competence : The roll of fatty acids and B-oxidation 148 R 15 - R 27

[21]. Yunus Ahmad, Andrabi Syed Mudasir, Hussain Altaf, W.A. Rashid, T. Mahesh (2013) : Biochemical Studies in muscle of fresh water fish exposed to heavy metals. Int J. Adv. Res. 3 (8) : 887-893.

[22]. Prusty A.K., Meena D.K.; Mahapatra S. Pannikar P., Das P., Gupta, S.K., \& Behra B.K. (2015) : Synthetic pyrethroids (TypeII) \& fresh water fish culture, Int Aquat. Res. $7: 163-191$.

[23]. . Dubey, J.K., Mishra D.B. \& Tripathi V.K.(2016): Evaluation of Biochemical Profile in liver tissues of two fish Channa punctatus \& Channa gachua exposed to deltamethrin. Research Spectra Vol.-II, Issue 2 \& 3, May Dec. 2016 (29-39).

[24]. N.Liyana Hannah Binti Izham Akmal,Anitha Roi(2017): Free radical Scavenging activity of fish oil-an in - Vitro study.Int-JPharm Sci.Res.(2017);8(9):3872-75. 